\title{
Pass-through, Exposure, and the Currency Composition of Debt
}

\author{
Michael Michaux* \\ Marshall School of Business \\ University of Southern California \\ Current version: January 2011
}

\begin{abstract}
I propose a model of production and financing for firms in an open economy, which features financial frictions and imperfect competition in the domestic goods market. The optimal currency composition of debt comes from the motive to hedge currency exposure, which arises from the industry equilibrium in the domestic goods market. Using a panel dataset of traded Mexican firms, I find evidence that firms hedge their foreign exchange rate exposure using foreign denominated debt. A calibrated version of the model is used to show that the hedging motive alone can rationalize the amount of foreign debt observed in the data, even the seemingly large amounts issued by firms with no exports.
\end{abstract}

JEL Codes: G30, G32.

Keywords: Pass-through, exchange rate exposure, balance sheet effects, capital structure, dollar debt, currency composition of debt.

\footnotetext{
${ }^{*}$ The author would like to thank Andy Abel, Lukasz Drozd, João Gomes, François Gourio, Urban Jermann, Karen Lewis, Dick Marston, Pricila Maziero, David Ng, and seminar participants at Cornell, Emory, Federal Reserve Bank of Philadelphia, Maryland, Notre Dame, Rice, University of British Columbia, University of California Berkeley, University of Minnesota, University of Southern California, Vanderbilt, and Wharton for comments and helpful discussions. The Weiss Center for International Financial Research is gratefully acknowledged. Suggestions are welcome. Please address correspondence to Michael Michaux, Department of Finance and Business Economics, Marshall School of Business, University of Southern California, 3670 Trousdale Parkway, BRI-308, Los Angeles, CA 90089. E-mail: michaux@marshall.usc.edu.
} 


\section{Introduction}

Firms that contract debt in foreign currency rather than in domestic currency can create currency exposures via balance sheet mismatches. These currency exposures can potentially lead to more costly external financing, or even bankruptcy when the exchange rate depreciates sharply. In addition, numerous papers ${ }^{1}$ have documented that exchange rate depreciations are associated with drops in real investment because of balance sheet effects. Therefore the currency composition of corporate debt is an important capital structure decision.

In the emerging markets literature there is mounting empirical evidence that shows that firms in emerging markets have a sizable amount of dollar-denominated debt. ${ }^{2}$ A natural attraction to dollar debt is that dollar interest rates are typically lower than the domestic ones. However dollar debt exposes firms to exchange rate fluctuations through a balance sheet currency mismatch. Several other explanations for the high dollar indebtedness have been offered in the theoretical literature. Schneider and Tornell (2004) argue that implicit guarantees by the government induce firms to borrow in dollars excessively. Expecting a bailout -implicit guarantees by the government- in the event of a large currency depreciation, firms issue large amounts of dollar debt and thus overexpose themselves to exchange rate fluctuations. Caballero and Krishnamurthy $(2001,2003)$ argue that limited financial development in emerging markets led to firms taking on excessive dollar debt. Specifically they show that when financial constraints affect borrowing and lending, firms undervalue insuring against an exchange rate depreciation and therefore take on excessive dollar debt. The existing theories of high dollar indebtedness are based on the presence of benefits to issuing dollar debt, which firms balance against the cost in the event of a large currency depreciation. In these models currency mismatches of assets and liabilities arise in equilibrium, and therefore firms' profits are exposed to fluctuations in the exchange rate.

In contrast, this paper argues that firms use dollar debt as a hedging tool against exchange rate risk. Specifically I argue that firms inherit an exposure to exchange rate risk in the goods market, via their sales, and that they issue the appropriate amount of dollar debt so as to reduce the impact of exchange rate fluctuations onto their earnings. This paper proposes a framework to address the question of how much dollar debt a firm should issue to hedge exchange rate risk. The model can be used as a laboratory to study the effect of goods market imperfections and financial frictions on the amount of dollar debt issuance. The model can be thought of as a benchmark for capital structure decisions -extended to include the currency composition of debt- of firms in open economies exposed to exchange rate risk.

In the first section of the paper, I describe a panel dataset of traded Mexican firms that I will use to calibrate the model in the numerical analysis. The first empirical fact is that firms tend to increase the proportion of dollar indebtedness as exports become a larger portion of their revenues and that local firms also issue large fractions of their debt in dollars although they do not export anything. The second

\footnotetext{
${ }^{1}$ See for example Gilchrist and Sim (2009). They use a panel data of Korean manufacturing firms to estimate a structural dynamic program. Counterfactual simulations show that balance sheet effects may account for $50 \%$ to $80 \%$ of the drop in investment during the crisis period.

${ }^{2}$ See Bleakley and Cowan (2008), Allayannis and Ofek (2001), and Aguiar (2005).
} 
empirical fact is that regressions of sales and earnings (defined as sales minus cost of good sold minus financing costs) on the exchange rate show that firms' sales are correlated with the exchange rate, but that their earnings are not. These empirical facts taken together are evidence that firms are able to reduce their exposure to the exchange rate using dollar denominated debt. I argue that firms use dollar denominated debt to essentially hedge the exposure they inherit through their sales.

In the second section of the paper, I propose a dynamic model of firms in an open economy. I incorporate a standard corporate finance model of the firm, similar in spirit to Cooley and Quadrini (2001), Gomes (2001), Hennessy and Whited (2005), and Gomes and Schmid (2009), into an industry equilibrium with imperfectly competitive goods market. The heterogeneity between firms comes from an idiosyncratic cost shock similar in spirit to Melitz (2003) and Melitz and Ottaviano (2008), making the decision to export endogenous. I also add financial frictions in the form of costly equity issuances and defaultable debt. Bankruptcy costs are incurred upon default and the interest expense on debt can be deducted from taxable income.

In the last section, I use the model to quantify how much of the dollar debt in the data can be accounted for by the hedging motive. The real side of the model is calibrated to resemble the data moments from the dataset of Mexican firms described in the empirical section. Parameters governing the financial frictions in the model are chosen such that the model is consistent with empirical levels of leverage. This quantitative exercise shows that the hedging motive alone can rationalize the amount of dollar debt observed in the Mexican data.

The model in this paper is similar in spirit to the static model of Bodnar, Dumas, and Marston (2002). The authors develop a model of exporting firms under imperfect competition to study the interaction between pass-through and exchange rate exposure. They study how changes in exchange rates affect the relative competitiveness of firms in the goods market through their production costs. In contrast, the model in this paper studies the domestic market and focuses on understanding how changes in exchange rates affect pass-through and exchange rate exposure of all firms in the domestic market. Local firms have a positive pass-through in the industry equilibrium, even though costs for all firms in this economy are similar. In addition this paper addresses the optimal currency composition of debt in such an economy, which is not considered in Bodnar, Dumas, and Marston (2002).

The paper is organized as follows. Section 2 describes the panel dataset of Mexican firms and derives a set of empirical facts that will serve as targets for the model. The model is described in Section 3. Finally the model is calibrated and used to quantify the optimal currency composition of debt in Section 4. Section 5 concludes the paper.

\section{Empirical Evidence}

This section presents the panel dataset of Mexican firms used in this section. First I used simple regressions to understand the determinants of debt currency composition for the Mexican firms. Then I estimate the exchange rate sensitivity of their sales, operating profits, and earnings. 


\subsection{Description of the Data}

The panel dataset has been constructed by gathering items from the balance sheets and the cash flow statements for a set of Mexican firms traded on the Mexican Stock Market (Bolsa Mexicana de Valores). The data items are recorded from the fourth quarter of 1999 to the second quarter of 2009. As it is customary, financial and insurance firms are excluded from the sample.

The dataset is composed of 99 firms, totaling 2,608 firm/quarter observations. It contains the following balance sheet items: book assets, book debt (including current liabilities and long term debt), decomposed into foreign (dollar-denominated) debt and domestic (peso-denominated) debt. The statements of cash flow contain quarterly figures for total sales, decomposed into foreign and domestic sales. These data items will allow the construction of the variables such as leverage (debt/assets), share of foreign debt, share of foreign sales, and asset turnover. The percentage of dollar debt will be the ratio of dollar denominated debt over total debt. The percentage of foreign sales is the ratio of foreign sales over total sales. Asset turnover is defined as the ratio of total sales over total assets. Table 1 reports the summary statistics for these variables. Panel A reports the data in levels in millions of Mexican pesos, and panel B reports the variables relevant to the empirical analysis.

Firms are classified into different industries of operation. Appendix B lists all the firms traded on the BMV broken down by industry. The industries include the following: Materials, Manufacturing, Consumer Goods and Services, Consumer Durables, Health Care, and Telecommunication Services. Each of the 6 industries is broken down further into sectors, for a total of 15 sectors.

Figure 1 plots the share of foreign debt versus the share of foreign sales for each firm. As it has been documented empirically in the emerging markets literature, there is a positive correlation between the share of foreign debt and the share of foreign sales. This observation is consistent with the view that firms engage in hedging their currency exposure. In addition the graph shows that many non-exporters have sizable shares of foreign debt.

\subsection{Currency Composition of Debt}

A simple regression analysis is conducted in this subsection. I run regressions of firms' share of foreign debt on firms' characteristics. A natural regressor in this context is the share of foreign sales. In addition I use typical regressors in the empirical corporate finance literature, such as firm size, leverage, and asset turnover. A dummy variable that indicates whether firms have ADR listings in the NYSE is used to control for access to international markets. Industry dummies are used to control for the industryspecific effects. The regression results are summarized in Table 2. The first main result from this

regression analysis is that the share of foreign sales is statistically significant at the $1 \%$ level in all the regression specifications. This relationship is robust even when controlling for all firm characteristics, and industry and quarter dummies. This result confirms the broad result in the emerging markets empirical literature that exporting firms hedge the currency exposure that originates from their export 
Panel A: Levels

\begin{tabular}{lccccc}
\hline \hline Variable & Obs. & Mean & Std. Dev. & Min & Max \\
\hline \hline Assets & 2,608 & 25,200 & 52,600 & 96.3 & 624,000 \\
\hline Sales & 2,608 & 4,780 & 9,418 & 0 & 94,400 \\
Domestic Sales & 2,608 & 3,546 & 6,800 & 0 & 72,700 \\
Foreign Sales & 2,608 & 1,239 & 4,488 & 0 & 59,200 \\
\hline Debt & 2,608 & 11,100 & 27,100 & 7.5 & 316,000 \\
Domestic Debt & 2,608 & 4,766 & 10,000 & 0 & 75,700 \\
foreign Debt & 2,608 & 6,354 & 19,500 & 0 & 276,000 \\
\hline \hline
\end{tabular}

Panel B: Ratios

\begin{tabular}{lccccc}
\hline \hline Variable & Obs. & Mean & Std. Dev. & Min & Max \\
\hline Share of Foreign Debt & 2,608 & 0.37 & 0.32 & 0 & 1 \\
Share of Foreign Sales & 2,608 & 0.15 & 0.21 & 0 & 0.86 \\
Debt/Assets & 2,608 & 0.38 & 0.20 & 0.005 & 1.69 \\
Total Sales/Assets & 2,608 & 0.21 & 0.14 & 0 & 1.03 \\
$\log$ (Assets) & 2,608 & 15.83 & 1.63 & 11.47 & 20.25 \\
\hline \hline
\end{tabular}

Panel C: Local versus Exporting Firms

\begin{tabular}{|c|c|c|c|c|c|c|}
\hline Firms & \multicolumn{3}{|l|}{ Local } & \multicolumn{3}{|c|}{ Exporter } \\
\hline Variable & Obs. & Mean & Std. Dev. & Obs. & Mean & Std. Dev. \\
\hline Share of Foreign Debt & 923 & 0.15 & 0.20 & 1,685 & 0.49 & 0.31 \\
\hline Share of Foreign Sales & 923 & 0 & 0 & 1,685 & 0.24 & 0.22 \\
\hline Debt/Assets & 923 & 0.30 & 0.18 & 1,685 & 0.43 & 0.20 \\
\hline Total Sales/Assets & 923 & 0.23 & 0.17 & 1,685 & 0.20 & 0.11 \\
\hline $\log$ (Assets) & 923 & 15.19 & 1.50 & 1,685 & 16.17 & 1.60 \\
\hline
\end{tabular}

Table 1: Summary Statistics. This table reports the summary statistics for the main variables. Panel A reports the raw data in millions of Mexican pesos. Panel B reports ratios. Panel C reports variables for local and exporting firms. The data consists of 99 traded Mexican firms, for the years 1999 to 2009. Source: Bolsa Mexicana de Valores. 


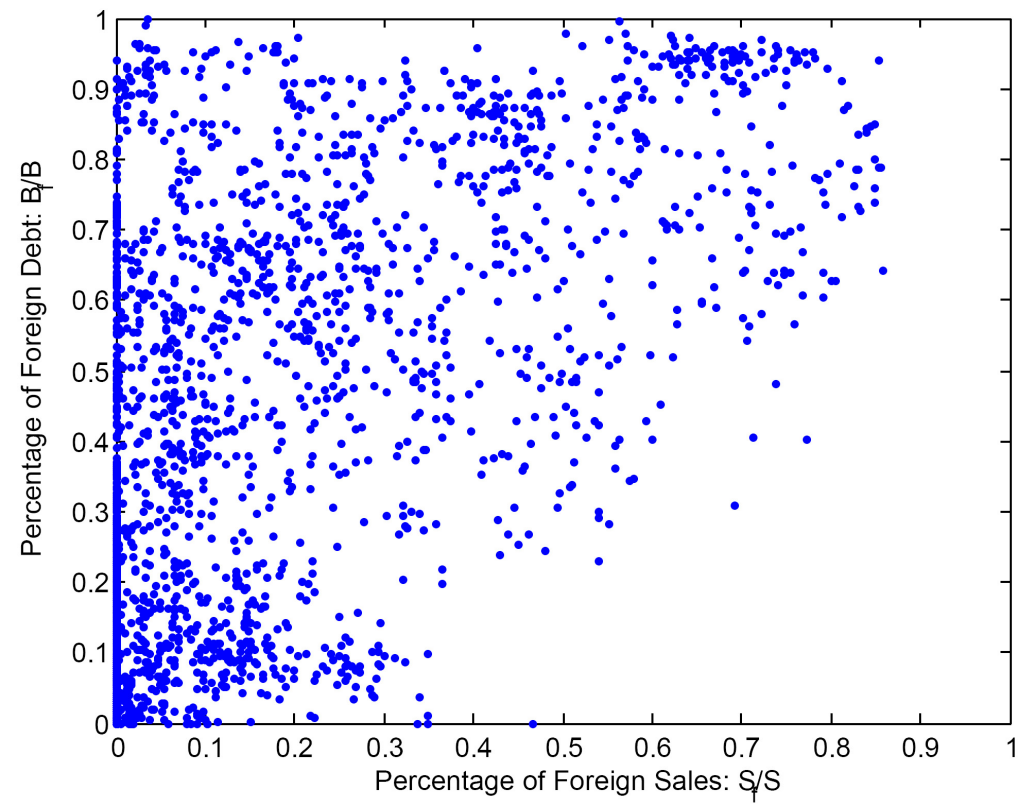

Figure 1: Share of Foreign Debt versus the Share of Foreign Sales. The data consists of Mexican firms traded on the Mexican Stock Market, for the years 1999 to 2009. Source: Bolsa Mexicana de Valores.

\begin{tabular}{lcccc}
\hline \hline Share of foreign Debt & $(1)$ & $(2)$ & $(3)$ & $(4)$ \\
\hline \hline Share of Foreign Sales & $0.926^{* * *}$ & $0.789^{* * *}$ & $0.870^{* * *}$ & $0.805^{* * *}$ \\
& $(47.37)$ & $(39.23)$ & $(40.77)$ & $(37.30)$ \\
Debt/Assets & & $0.374^{* * *}$ & & $0.336^{* * *}$ \\
& & $(13.91)$ & $(13.26)$ \\
$\log$ (Assets) & $0.012^{* * *}$ & & $0.005^{*}$ \\
& & $(4.27)$ & & $(1.75)$ \\
Sales/Assets & & $-0.521^{* * *}$ & & $-0.424^{* * *}$ \\
& & $(-18.30)$ & & $(-11.67)$ \\
ADR Dummy & & $0.026^{* *}$ & & $-0.021^{*}$ \\
& & $(2.05)$ & & $(-1.65)$ \\
Constant & $0.224^{* * *}$ & 0.018 & & \\
& $(37.08)$ & $(0.41)$ & & \\
\hline Industry Dummy & No & No & Yes & Yes \\
\hline R-squared & 0.384 & 0.494 & 0.495 & 0.546 \\
N & 2,608 & 2,608 & 2,608 & 2,608 \\
\hline \hline
\end{tabular}

Table 2: Regression Results. Level of significance: ${ }^{*} p<0.1,{ }^{* *} p<0.05,{ }^{* * *} p<0.01$, using robust standard errors. 
activities. However the first regression (column 1) shows that the average share of foreign debt for firms with no exports is about $22 \%$. This seems to be a puzzle as these firms have no direct exposure to the exchange rate.

Depending on the industry within which firms are operating, access to financing, sales, and cost of production may have different sensitivities to exchange rate fluctuations. These differences across industries will impact optimal debt composition in a systematic way. The addition of industry dummies (i.e. columns 3 and 4 of Table 2) increases the explanatory power. This confirms the presence of the exchange rate sensitivity channel, acting at the industry level.

\begin{tabular}{lccc}
\hline \hline & $(1)$ & $(2)$ & $(3)$ \\
& Sales/Assets & Operating Income/Assets & Earnings/Assets \\
\hline \hline $\log (\mathrm{e})$ & $0.067^{* * *}$ & $0.006^{*}$ & -0.009 \\
& $(6.34)$ & $(1.65)$ & $(-1.13)$ \\
$\log (\mathrm{GDP})$ & $0.088^{* * *}$ & $0.036^{* * *}$ & $0.033^{* *}$ \\
& $(4.76)$ & $(5.15)$ & $(2.32)$ \\
\hline Debt/Assets & -0.006 & $-0.021^{* * *}$ & $-0.059^{* * *}$ \\
& $(-0.62)$ & $(-6.37)$ & $(-10.04)$ \\
$\log ($ Assets) & $-0.016^{* * *}$ & $0.004^{* * *}$ & $0.006^{* * *}$ \\
& $(-5.92)$ & $(5.48)$ & $(6.50)$ \\
ADR Dummy & 0.0008 & -0.002 & -0.0007 \\
& $(0.08)$ & $(-0.64)$ & $(-0.18)$ \\
\hline \hline Firm Fixed Effect & Yes & Yes & Yes \\
Quarter Dummy & Yes & Yes & Yes \\
\hline R-squared (within) & 0.053 & 0.030 & 0.037 \\
R-squared (between) & 0.011 & 0.309 & 0.369 \\
N & 2,608 & 2,608 & 2,608 \\
\hline \hline
\end{tabular}

Table 3: Regression Results. These regressions use local firms only. Level of significance: ${ }^{*} p<0.1$, ** $p<0.05, * * * p<0.01$, using robust standard errors.

\subsection{Estimation of the Exchange Rate Sensitivities}

The time dimension of the panel permits the estimation of the foreign exchange rate exposure of firm earnings. The exchange rate sensitivity of sales and earnings can be estimated for each firm by running a regression of sales and earnings on the log of the exchange rate. Because accounting data are noisy, the exposure will not be estimated at the firm level, but rather firms will be pooled together. Firm fixedeffect regressions are used to estimate the exposure of sales, operating income (defined as sales minus 
cost of good sold), and earnings (defined as sales minus cost of good sold minus financing expenses).

Sales, operating income, and profits over a 10-year period have trends, thus instead of regressing the level of sales and earnings, their ratio over assets will be used as independent variables. The regression specification is given by,

$$
Y_{i t}=\alpha_{i}+\beta_{e} \log \left(e_{t}\right)+\beta_{G D P} \log \left(G D P_{t}\right)+\beta X_{i t}+\varepsilon_{i t}
$$

where the independent variables will be: sales (column 1), operating income (column 2), and earnings (column 3). Note that all of these variables are normalized by total assets. The aggregate states are included in the regressions: exchange rate, $\log (e)$, as well as the residuals of the Hodrick-Prescott filter of the logarithm of the Mexican GDP, denoted by $\log (G D P)$. In addition, firm characteristics $X_{i t}$ are used as control variables: leverage, size, and ADR dummy. In addition a quarter dummy is added to control for seasonality.

Table 3 reports the regression results for all firms. It can be seen that sales have a statistically significant positive sensitivity to the exchange rate, however earnings do not. These results are evidence that firms are in fact hedging their exchange rate risk effectively, insulating their earnings from exchange rate fluctuations.

\section{Quantitative Model}

This section presents an industry equilibrium of firms that make production and financing decisions. The model is fully dynamic and has been extended to accommodate a continuum of firms. The heterogeneity between firms comes from an idiosyncratic cost shock similar in spirit to Melitz (2003), thus the decision to export is endogenous in this economy. Financial frictions have been added, in the form of costly equity issuances and costly default on debt. Bankruptcy costs are incurred upon default on the debt and the interest expense on debt can be deducted from taxable income. These ingredients are standard in the corporate finance literature ${ }^{3}$. Such a framework can be used to study the effect of imperfect competition in the domestic goods market on firms' share of foreign debt.

\subsection{Preferences}

Preferences are defined over a continuum of differentiated goods indexed by $i \in \Omega$. All domestic consumers share the same utility function given by,

$$
U=\left(\int_{i \in \Omega} x_{i}^{\rho} d i\right)^{\frac{1}{\rho}},
$$

where $x_{i}$ represents the consumption level of each variety $i$. The parameter $\rho \in[0,1]$ governs the elasticity of substitution between each good. Let $X$ denote the aggregate good,

$$
X \equiv\left(\int_{i \in \Omega} x_{i}^{\rho} d i\right)^{\frac{1}{\rho}} .
$$

\footnotetext{
${ }^{3}$ See Cooley and Quadrini (2001), Gomes (2001), Hennessy and Whited (2005), and Gomes and Schmid (2009)
} 
This consumer problem yields a set of domestic price schedules $p_{i}$ (i.e. demand curves) for each variety $i$,

$$
p_{i}\left(x_{i}, X\right)=y x_{i}^{\rho-1} X^{-\rho}, \quad i \in \Omega
$$

where $y$ is the total expenditure in the domestic market. Note that price of variety $i$ is decreasing in the supply of both its own quantity and in the quantity of aggregate good supplied. The case of perfect substitutes is obtained by taking the limit of parameter $\rho$ to one. The demand curve for the homogeneous good is simply $p(X)=y X^{-1}$.

Consumers in the foreign economy value good $i$ according to an exogenous demand curve, denoted by $p_{i}^{*}\left(x_{i}^{*}\right)$. This economy is thus a small open economy exporting to a large open economy.

\section{$3.2 \quad$ Firm Problem}

The dynamic programming problem for firm $i$ is to choose domestic debt $\hat{b}_{i d}^{\prime}$, foreign debt $\hat{b}_{i f}^{\prime}$, domestic and foreign sales $x_{i}$ and $x_{i}^{*}$, and a default policy to maximize the present value of dividends. The exchange rate $e$ and the idiosyncratic cost shock $z_{i}$ are exogenous shocks.

Firms can choose the scale of the operation instantaneously but incur a convex cost of production. Firms can sell its production in the domestic market and in the foreign market. The sales are denoted by $x_{i}$ and $x_{i}^{*}$, respectively. Profits for firm $i$ are given by the following program,

$$
\pi_{i}\left(z_{i}, e\right)=\max _{x_{i}, x_{i}^{*}} \quad p_{i} x_{i}+e p_{i}^{*} x_{i}^{*}-\frac{\eta_{1}}{\eta_{2}} \exp \left(z_{i}\right)\left(x_{i}+x_{i}^{*}\right)^{\eta_{2}}-f^{*} \mathbf{1}_{\left\{x_{i}^{*}>0\right\}}-f
$$

where $\eta_{1}>0$ and $\eta_{2}>1$ are parameters of the cost function, $f^{*}$ is a fixed cost paid if the firm exports, $f$ is a fixed cost of operation, and $p_{i}^{*}$ is the price (in foreign currency units) of the good sold in the foreign market.

Firms have access to international lenders and can borrow in the form of one-period debt contracts. Domestic debt is denominated in local currency units, while foreign debt is denominated in foreign currency units. The coupon rate for a newly issued domestic bond is denoted $c_{i d}^{\prime}$, while the coupon for the foreign bond is $c_{i f}^{\prime}$. Both bonds will be priced competitively by international investors assuming that markets are complete.

Profits are taxed at a rate $\tau \in[0,1]$ and interest expense can be deducted from taxable income. The dividend for the firm is defined as the sum of after-tax profits and new debt issues, net of debt repayment,

$$
\tilde{d}_{i}=(1-\tau) \pi_{i}\left(z_{i}, e\right)+\hat{b}_{i d}^{\prime}+e \hat{b}_{i f}^{\prime}-\hat{b}_{i d}\left(1+(1-\tau) c_{i d}^{\prime}\right)-e \hat{b}_{i f}\left(1+(1-\tau) c_{i f}^{\prime}\right),
$$

Financing frictions are present in the form of costly equity issuances. Following Gomes (2001), equity can be issued at a proportional $\operatorname{cost} \lambda$, that is dividend net of equity issuance is given by,

$$
d_{i}=\left(1+\lambda \mathbf{1}_{\left\{\tilde{d}_{i}<0\right\}}\right) \tilde{d}_{i}
$$

where $\mathbf{1}_{\left\{\tilde{d}_{i}<0\right\}}$ is the indicator function of strictly negative dividends, i.e. $\mathbf{1}_{\left\{\tilde{d}_{i}<0\right\}}=1$ if $\tilde{d}_{i}<0$ (and 0 otherwise). 
The value of the firm continuing operations is given by,

$$
V_{i}\left(\hat{b}_{i d}, \hat{b}_{i f}, s\right)=\max _{\hat{b}_{i d}^{\prime}, \hat{b}_{i f}^{\prime}, x_{i}, x_{i}^{*}} d_{i}+\mathbb{E}\left[m_{d}\left(s, s^{\prime}\right) \max \left(0, V_{i}\left(\hat{b}_{i d}^{\prime}, \hat{b}_{i f}^{\prime}, s^{\prime}\right)\right)\right],
$$

where $m_{d}\left(s, s^{\prime}\right)$ is the stochastic discount factor that firms take as given. The vector $s$ contains all the exogenous state variables in the economy. Specifically, the exchange rate $e$ and the idiosyncratic cost shock $z_{i}$ are included in the exogenous state vector. The transition function for $s$ will be described in detail in Section 3.4 .

\subsection{International Markets and Lenders}

This model assumes the existence of complete markets. This assumption allows the consideration of only one pricing kernel, in this case the domestic one. In other words, the foreign pricing kernel is given by,

$$
m_{f}\left(s, s^{\prime}\right)=m_{d}\left(s, s^{\prime}\right) \frac{e^{\prime}}{e}
$$

There is a continuum of competitive lenders. The emerging economy is small in comparison to the international markets, thus the international lenders pricing kernel $m_{f}\left(s, s^{\prime}\right)$ is taken as exogenous. Any debt contract has to satisfy the international lenders' Euler equation. Risky dollar debt $\hat{b}_{i f}^{\prime}$ will be supplied to firm $i$ at a coupon rate $c_{i f}^{\prime}$ such that,

$$
\hat{b}_{i f}^{\prime}=\mathbb{E}\left[m_{d}\left(s, s^{\prime}\right) \frac{e^{\prime}}{e}\left\{\left(1+c_{i f}^{\prime}\right) \hat{b}_{i f}^{\prime} \mathbf{1}^{\prime}+\xi \frac{e^{\prime}\left(1+c_{i f}^{\prime}\right) \hat{b}_{i f}^{\prime}}{\left(1+c_{i d}^{\prime}\right) \hat{b}_{i d}^{\prime}+e^{\prime}\left(1+c_{i f}^{\prime}\right) \hat{b}_{i f}^{\prime}} \frac{\pi_{i}^{\prime}+f^{*}+f}{e^{\prime}}\left(1-\mathbf{1}^{\prime}\right)\right\}\right]
$$

where $\mathbf{1}^{\prime}$ is the indicator function for the decision to continue operations, that is if $V_{i}^{\prime} \geq 0$. The bankruptcy costs are captured by the parameter $\xi \in[0,1]$, which represents the percentage of current profits that is recovered by debtholders after the firm is sold or reorganized. Similarly lenders will supply risky peso debt $\hat{b}_{i d}^{\prime}$ to firm $i$ at a coupon rate $c_{i d}^{\prime}$ such that,

$$
\hat{b}_{i d}^{\prime}=\mathbb{E}\left[m_{d}\left(s, s^{\prime}\right)\left\{\left(1+c_{i d}^{\prime}\right) \hat{b}_{i d}^{\prime} \mathbf{1}^{\prime}+\xi \frac{\left(1+c_{i d}^{\prime}\right) \hat{b}_{i d}^{\prime}}{\left(1+c_{i d}^{\prime}\right) \hat{b}_{i d}^{\prime}+e^{\prime}\left(1+c_{i f}^{\prime}\right) \hat{b}_{i f}^{\prime}}\left(\pi_{i}^{\prime}+f^{*}+f\right)\left(1-\mathbf{1}^{\prime}\right)\right\}\right] .
$$

Define $b$ to be debt inclusive of interest payment and net of tax shield subsidy,

$$
b_{i d} \equiv\left(1+(1-\tau) c_{i d}\right) \hat{b}_{i d}, \quad b_{i f} \equiv\left(1+(1-\tau) c_{i f}\right) \hat{b}_{i f}
$$

The pricing equations can be rewritten as follows,

$$
\begin{aligned}
& \hat{b}_{i f}^{\prime}=\frac{\mathbb{E}\left[m_{d}\left(s, s^{\prime}\right) \frac{e^{\prime}}{e}\left\{\frac{1}{1-\tau} b_{i f}^{\prime} \mathbf{1}^{\prime}+\xi \frac{e^{\prime} b_{i f}^{\prime}}{b_{i d}^{\prime}+e^{\prime} b_{i f}^{\prime}} \frac{\pi_{i}^{\prime}+f^{*}+f}{e^{\prime}}\left(1-\mathbf{1}^{\prime}\right)\right\}\right]}{1+\frac{\tau}{1-\tau} \mathbb{E}\left[m_{d}\left(s, s^{\prime}\right) \frac{e^{\prime}}{e} \mathbf{1}^{\prime}\right]}, \\
& \hat{b}_{i d}^{\prime}=\frac{\mathbb{E}\left[m_{d}\left(s, s^{\prime}\right)\left\{\frac{1}{1-\tau} b_{i d}^{\prime} \mathbf{1}^{\prime}+\xi \frac{b_{i d}^{\prime}}{b_{i d}^{\prime}+e^{\prime} b_{i f}^{\prime}}\left(\pi_{i}^{\prime}+f^{*}+f\right)\left(1-\mathbf{1}^{\prime}\right)\right\}\right]}{1+\frac{\tau}{1-\tau} \mathbb{E}\left[m_{d}\left(s, s^{\prime}\right) \mathbf{1}^{\prime}\right]} .
\end{aligned}
$$




\subsection{Dynamics of the Shocks}

The exchange rate process is the only source of uncertainty at the aggregate level. The exchange rate is exogenous from the point of view of the firms. This paper does not take a stand on how it is determined. All firms face idiosyncratic shocks to their cost, denoted by $z_{i}$. In addition to these shocks, the exchange rate from the previous period is also required. Thus the vector of exogenous state, denoted by $s$, is defined as $s \equiv\left(z_{i}, e, e_{-1}\right)$.

\subsection{Recursive Formulation of the Firm Problem}

For computational reasons, it is convenient to rewrite the problem in terms of the firm's total debt $b$ and its share of foreign debt $\omega$, instead of the domestic debt $b_{d}$ and the foreign debt $b_{f}$. Define,

$$
\omega^{\prime} \equiv \frac{e b_{f}^{\prime}}{b_{d}^{\prime}+e b_{f}^{\prime}} \quad \text { and } \quad b^{\prime} \equiv b_{d}^{\prime}+e b_{f}^{\prime} .
$$

Dividend can be rewritten as follows,

$$
d_{i}=\left(1+\lambda \mathbf{1}_{\left\{d_{i}<0\right\}}\right)\left\{(1-\tau) \pi_{i}\left(z_{i}, e\right)+q_{i}^{\prime} b_{i}^{\prime}-\left(1-\omega_{i}+\frac{e}{e_{-1}} \omega_{i}\right) b_{i}\right\} .
$$

where the discount price of total debt $q_{i}^{\prime}$ is given in equation (9). Similarly, the coupon rates can be written in terms of total debt and foreign share,

$$
\begin{aligned}
& c_{i f}^{\prime}=\frac{1}{1-\tau}\left(\frac{1+\frac{\tau}{1-\tau} \mathbb{E}\left[m_{d}\left(s, s^{\prime}\right) \frac{e^{\prime}}{e} \mathbf{1}^{\prime}\right]}{\mathbb{E}\left[m_{d}\left(s, s^{\prime}\right) \frac{e^{\prime}}{e}\left\{\frac{1}{1-\tau} \mathbf{1}^{\prime}+\xi \frac{\frac{e^{\prime}}{e}}{1-\omega_{i}^{\prime}+\frac{e^{\prime}}{e} \omega_{i}^{\prime}} \frac{\pi_{i}^{\prime}+f^{*}+f}{b_{i}^{\prime}}\left(1-\mathbf{1}^{\prime}\right)\right\}\right]}-1\right), \\
& c_{i d}^{\prime}=\frac{1}{1-\tau}\left(\frac{1+\frac{\tau}{1-\tau} \mathbb{E}\left[m_{d}\left(s, s^{\prime}\right) \mathbf{1}^{\prime}\right]}{\mathbb{E}\left[m_{d}\left(s, s^{\prime}\right)\left\{\frac{1}{1-\tau} \mathbf{1}^{\prime}+\xi \frac{1}{1-\omega_{i}^{\prime}+\frac{e^{\prime}}{e} \omega_{i}^{\prime}} \frac{\pi_{i}^{\prime}+f^{*}+f}{b_{i}^{\prime}}\left(1-\mathbf{1}^{\prime}\right)\right\}\right]}-1\right) .
\end{aligned}
$$

The firm's problem can now be stated in terms of the total debt and foreign share.

Problem 1 (Recursive Formulation of Firm $i$ 's Problem) Given the price schedules $p_{i}\left(x_{i}, X\right)$, $c_{i f}^{\prime}\left(b_{i}^{\prime}, \omega_{i}^{\prime}, s\right)$, and $c_{i d}^{\prime}\left(b_{i}^{\prime}, \omega_{i}^{\prime}, s\right)$, firm $i$ solves the following program,

$$
V_{i}\left(b_{i}, \omega_{i}, s\right)=\max _{b_{i}^{\prime}, \omega_{i}^{\prime}} d_{i}+\mathbb{E}\left[m_{d}\left(s, s^{\prime}\right) \max \left(0, V_{i}\left(b_{i}^{\prime}, \omega_{i}^{\prime}, s^{\prime}\right)\right)\right]
$$

subject to,

$$
\begin{aligned}
d_{i} & =\left(1+\lambda \boldsymbol{1}_{\left\{d_{i}<0\right\}}\right)\left\{(1-\tau) \pi_{i}\left(z_{i}, e\right)+q_{i}^{\prime} b_{i}^{\prime}-\left(1-\omega_{i}+\frac{e}{e_{-1}} \omega_{i}\right) b_{i}\right\}, \\
\pi_{i}\left(z_{i}, e\right) & =\max _{x_{i}, x_{i}^{*}} p_{i} x_{i}+e p_{i}^{*} x_{i}^{*}-\frac{\eta_{1}}{\eta_{2}} \exp \left(z_{i}\right)\left(x_{i}+x_{i}^{*}\right)^{\eta_{2}}-f^{*} \boldsymbol{1}_{\left\{x_{i}^{*}>0\right\}}-f,
\end{aligned}
$$

where the discount price of total debt issued is,

$$
q_{i}^{\prime}=\frac{1-\omega_{i}^{\prime}}{1+(1-\tau) c_{i d}^{\prime}}+\frac{\omega_{i}^{\prime}}{1+(1-\tau) c_{i f}^{\prime}} .
$$




\subsection{Competitive Equilibrium}

Now that the problems for the representative consumer, the international lenders, and firms have been defined, the competitive equilibrium can be formally stated.

Definition 2 (Recursive Competitive Equilibrium) A recursive competitive equilibrium consists of pricing functions $p_{i}\left(x_{i}, X\right), c_{i d}^{\prime}\left(b_{i}^{\prime}, \omega_{i}^{\prime}, s\right)$, and $c_{i f}^{\prime}\left(b_{i}^{\prime}, \omega_{i}^{\prime}, s\right)$, value functions $V_{i}\left(b_{i}, \omega_{i}, s\right)$, and optimal decision rules $g_{i, b^{\prime}}\left(b_{i}, \omega_{i}, s\right), g_{i, \omega^{\prime}}\left(b_{i}, \omega_{i}, s\right), g_{i, x}(s)$, and $g_{i, x^{*}}(s)$, such that:

1. Consumer's Optimization: Price functions $p_{i}\left(x_{i}, X\right)$ satisfy the following conditions:

$$
p_{i}\left(x_{i}, X\right)=y x_{i}^{\rho-1} X^{-\rho}, \quad i \in \Omega,
$$

where

$$
X=\left(\int_{i \in \Omega} x_{i}^{\rho} d i\right)^{\frac{1}{\rho}}
$$

2. International Lenders: Coupon schedules $c_{i d}^{\prime}\left(b_{i}^{\prime}, \omega_{i}^{\prime}, s\right)$, and $c_{i f}^{\prime}\left(b_{i}^{\prime}, \omega_{i}^{\prime}, s\right)$ satisfy the following Euler equations (4) and (5).

3. Firms' Optimization: Value functions $V_{i}(b, \omega, s)$ solve the Bellman equation (6), subject to constraints (7), (8), and (9). The associated optimal decision rules for firm $i$ are denoted by: $b_{i}^{\prime}=g_{i, b^{\prime}}(b, \omega, s), \omega_{i}^{\prime}=g_{i, \omega^{\prime}}(b, \omega, s), x_{i}=g_{i, x}(s)$, and $x_{i}^{*}=g_{i, x^{*}}(s)$.

4. Aggregate Consistency: The aggregate good $X(e)$ is consistent with the actual law of motion implied by the optimal decision rules $g_{i, x}(s)$ and the transition matrix for $s$,

$$
X(e)=\left(\int_{z_{i}} g_{i, x}\left(z_{i}, e\right)^{\rho} d G\left(z_{i}\right)\right)^{\frac{1}{\rho}},
$$

where $G$ is the unconditional distribution of idiosyncratic shocks $z_{i}$.

There are no closed-form expressions for this equilibrium. However numerical techniques can be employed to solve it. The next section will present numerical solutions for this economy.

\section{Numerical Results}

First I present the calibration strategy for the exogenous shocks in the model: the exchange rate process and the idiosyncratic shock process. Then I choose a reasonable set of model parameters based on various studies in the corporate finance literature. Finally I present some simulation results of the model to study the amount of dollar debt firms issue. 


\subsection{Calibration}

\subsubsection{Exchange Rate Process}

The real exchange rate series is constructed from the nominal exchange rate and the inflation data. The details are shown in Appendix C. The statistical properties of the real exchange rate are summarized in Panel A of Table 4. For simplicity, the real exchange rate process is assumed to follow an AR(1) process in the logarithm,

$$
\log \left(e_{t+1}\right)=c+\rho_{e} \log \left(e_{t}\right)+\sigma_{e} \epsilon_{t}
$$

The estimated parameters are shown in the panel B of Table 4. The process (10) is transformed into a discrete Markov chain using the Tauchen and Hussey (1991) procedure, using 11 points.

Panel A: Statistics

\begin{tabular}{lccc}
\hline \hline & $\mu\left(e_{t}\right)$ & $\sigma\left(e_{t}\right)$ & $\rho\left(e_{t}, e_{t-1}\right)$ \\
\hline Estimates (1994-2009) & 3.4158 & 0.7412 & 0.9017 \\
Estimates (1999-2009) & 3.0432 & 0.2305 & 0.7038 \\
\hline \hline
\end{tabular}

Panel B: AR(1) Estimates

\begin{tabular}{lccl}
\hline \hline & $c$ & $\sigma_{e}$ & $\rho_{e}$ \\
\hline Estimates (1994-2009) & 0.3359 & 0.3205 & 0.9017 \\
Estimates (1999-2009) & 0.9015 & 0.1638 & 0.7038 \\
\hline \hline
\end{tabular}

Table 4: Statistics and AR(1) Estimates of the Real Exchange Rate Process. Panel A reports the statistics for the real exchange rate process. Panel B reports the parameter estimates when the real exchange rate is assumed to follow an $\mathrm{AR}(1)$ process, given by $\log \left(e_{t+1}\right)=c+\rho_{e} \log \left(e_{t}\right)+\sigma_{e} \epsilon_{t}$. The results are shown for two different time periods. The data frequency is quarterly.

\subsubsection{Cost Parameters}

The variables in the model are mapped to data according to Table 5 . The various cost parameters: $\eta_{1}, \eta_{2}, f$, and $f^{*}$ and the preference parameters: $y$ and $p_{i}^{*}$ are chosen such that the first moments of the simulations match their data counterpart for various variables in the real side, given in Table 6 . The domestic consumer has a subjective discount rate $\beta$, which is chosen to correspond to a $3 \%$ yearly risk-free interest rate. The deterministic steady state of this economy is used for the purpose of this calibration exercise. The exchange rate and the cost shocks are set to their steady state value, that is $\bar{e}=\bar{z}=0$. The steady state production and sales policies are solved as a function of the model parameters. These expressions are used to match 3 first moments of the data: (Domestic Sales/Assets), (Foreign Sales/Assets), and (Profits/Assets). The details of the algebra can be found in Appendix D. The parameter values for the cost parameters are reported in Table 7 . The cost process $z_{i}$ is parameterized 


\begin{tabular}{lc}
\hline \hline Data & Model \\
\hline \hline Real Side: & \\
\hline Total Assets & $x_{i}+x_{i}^{*}$ \\
Total Sales & $p_{i} x_{i}+e p_{i}^{*} x_{i}^{*}$ \\
Domestic Sales & $p_{i} x_{i}$ \\
Foreign Sales & $e p_{i}^{*} x_{i}^{*}$ \\
Cost & $\pi_{i}=p_{i} x_{i}+e p_{i}^{*} x_{i}^{*}-\left(\frac{\eta_{1}}{\eta_{2}} \exp \left(z_{i}\right)\left(x_{i}+x_{i}^{*}\right)^{\eta_{2}}+f^{*}+f\right)$ \\
Profits & $\pi_{i} /\left(p_{i} x_{i}+e p_{i}^{*} x_{i}^{*}\right)$ \\
\hline Profit Margin & $p_{i} x_{i} / \int_{i} p_{i} x_{i} d G\left(z_{i}\right)$ \\
Market Share & \\
\hline \hline Financing Side: & $b_{i}^{\prime}$ \\
\hline Total Debt & $\left(1-\omega_{i}^{\prime}\right) b_{i}^{\prime}$ \\
Domestic Debt & $\omega_{i}^{\prime} b_{i}^{\prime}$ \\
Foreign Debt & $\left(q_{i}^{\prime}\right)^{-1}-\beta^{-1}$ \\
\hline Corporate Spread
\end{tabular}

Table 5: Mapping of Variables from the Model to Data.

along the lines of Gomes (2001) and Hennessy and Whited (2005). I assume the cost process to be a persistent process with persistence $\rho_{z}$, with volatility $\sigma_{e}$. The shock process is represented by a discrete Markov chain using 11 points. The parameters are reported in Table 7.

\subsubsection{Institutional Parameters}

The institution parameters are chosen following previous work in the corporate finance literature. Cost of equity issuances are chosen to be $15 \%$. This figure seems reasonable as Hennessy and Whited (2008) estimated these issuance costs to be about $6 \%$ using the simulated method of moments with US data. It is certainly plausible to believe that equity markets in Mexico have more informational asymmetry than in the US. The average tax rate is chosen to be $25 \%$. Bankruptcy costs are assumed to correspond to a dead-weight cost of $20 \%$ of current production, thus the recovery rate is set to $\xi=0.8$. Lastly the pricing kernel used to discount firms' cashflows and price the debt is chosen to be equal to the subjective discount rate $\beta$. The set of parameters used to solve the model are summarized in Table 7 .

\subsection{Production and Sales Policy}

Cost shocks are the only idiosyncratic shocks in these numerical examples. The foreign prices $p_{i}^{*}$ are constant. Figure 2 shows profits $\pi_{i}\left(z_{i}, e\right)$, sensitivity of profits $d \pi_{i}\left(z_{i}, e\right) / d e$, domestic $x_{i}\left(z_{i}, e\right)$ and foreign $x_{i}^{*}\left(z_{i}, e\right)$ sales as a function of the exchange rate $e$ and idiosyncratic cost shock $z_{i}$, for different values of the elasticity of substitution. These graphs will give some intuition about the basic margins 


\begin{tabular}{l|c|ccc}
\hline \hline Sample of firms & All & $\begin{array}{c}\text { Bin \#1 } \\
\text { (Local) }\end{array}$ & Bin \#2 & $\begin{array}{c}\text { Bin \#3 } \\
\text { (Exporter) }\end{array}$ \\
\hline \hline Real Side & \multicolumn{5}{|l}{} \\
\hline Total Sales/Assets & 21.2 & 22.8 & 22.3 & 18.6 \\
Domestic Sales/Assets & 18.3 & 22.8 & 21.1 & 10.9 \\
Foreign Sales/Assets & 3 & 0 & 1.1 & 7.7 \\
Profits/Assets & 1.6 & 1.8 & 1.8 & 1.1 \\
\hline Financing Side & \multicolumn{5}{|l}{} \\
\hline Debt/Assets & 38.3 & 29.9 & 41.9 & 43.8 \\
Foreign Debt/Assets & 16.3 & 4.6 & 15.9 & 28.9 \\
Share of Foreign Debt & 36.7 & 14.9 & 34.1 & 62 \\
\hline \hline
\end{tabular}

Table 6: Target Moments for Calibration. All the numbers in this table are given in percentage points.

\begin{tabular}{lll}
\hline \hline \multirow{2}{*}{ Preference } & $\beta=0.992$ & Risk free rate \\
& $\rho \in\{0.25,0.5,0.75\}$ & Substitutability of goods \\
& $y=3.6$ & Consumer expenditure \\
& $p_{i}^{*}=0.145$ & Foreign prices \\
\hline & $\eta_{1}=0.006$ & Production cost parameter \\
& $\eta_{2}=2$ & Production cost parameter \\
& $f=2.1$ & Fixed cost of operation \\
& $f^{*}=0.6$ & Fixed cost of exporting \\
\hline \multirow{3}{*}{ Institution } & $\lambda=0.15$ & Linear cost of issuing equity \\
& $\xi=0.8$ & Recovery rate in event of bankruptcy \\
& $\tau=0.25$ & Average corporate tax rate \\
\hline \multirow{2}{*}{ Exchange Rate } & $\rho_{e}=0.7$ & Long-run mean for $e$ \\
& $\sigma_{e}=0.15$ & Autocorrelation for $e$ \\
\hline Idiosyncratic Cost & $\rho_{z}=0$ & Volatility for $e$ \\
\hline \hline
\end{tabular}

Table 7: Parameter Values. 
in the equilibrium sales decisions. Total production and exports are decreasing in the cost. This result is fairly intuitive. As the firm becomes more productive, i.e. cost decreases, it can produce more units. As more units are being sold, domestic prices decrease up to the point where the foreign price becomes more attractive. Total production and exports are increasing in the exchange rate. This result follows a similar intuition. As the exchange rate appreciates, foreign prices (in peso) increase and thus exporting becomes more profitable. This will drive firms to produce more and export more. As expected, profits follow the monotonicity properties of total production, i.e. decreasing in the cost and increasing in the exchange rate. Because profits are convex in both arguments, it follows that the sensitivity of profits to $e$ is also decreasing in the cost and increasing in the exchange rate. Thus the most productive firms have the highest sensitivity of profits to the exchange rate. This property will be crucial for the optimal capital structure.

Following the exchange rate literature, pass-through is defined as the elasticity of price with respect to the exchange rate. It is denoted by $\eta\left(z_{i}, e\right)$ for a firm hit with shock $z_{i}$ and formally expressed as follows,

$$
\eta\left(z_{i}, e\right) \equiv \frac{\partial \log p_{i}\left(z_{i}, e\right)}{\partial \log e} .
$$

Pass-through is a measure of the extent to which a firm "passes through" the changes in exchange rates onto the price it charges in the goods market. In this model, we are interested in understanding how much of the exchange rate changes are passed onto the prices of all goods in the domestic market. The dollar price of the exported good is independent of the exchange rate by assumption, so its pass-through is zero. If the domestic goods market were perfectly competitive, prices would not react to changes in the supply of any goods and, as a result, pass-through for all firms would be zero. Thus the exchange rate fluctuations are transmitted to the price of other goods because of the domestic sales of firm hit by shock $z_{i}$, due to the imperfect competition in the domestic goods market. In the exchange rate exposure literature, pass-through generally results from a change in relative costs of production between firms. In this case a change in exchange rate leads to a change in the opportunity cost for the exporting firms. Thus this model highlights a channel for pass-through that links firms in the tradable sector to firms in the non-tradable sector.

The quantity of interest for the financing decision is not pass-through but rather the exchange rate exposure. It is defined as the elasticity of profits with respect to the exchange rate. It is denoted by $\delta\left(z_{i}, e\right)$ for a firm hit with shock $z_{i}$ and formally expressed as follows,

$$
\delta\left(z_{i}, e\right) \equiv \frac{\partial \log \pi\left(z_{i}, e\right)}{\partial \log e} .
$$

As pass-through and exposure are two statistics central to the financing decisions of firms, Figure 3 shows the pass-through $\eta\left(z_{i}, e\right)$ and exposure $\delta\left(z_{i}, e\right)$ as a function of exchange rate $e$ and cost shock $z_{i}$. Both pass-through and exposure are decreasing in the cost and increasing in the exchange rate. However the interesting feature is that firms can have no exports but strictly positive exposure. An increase in the elasticity of substitution leads to an increase in both pass-through and exposure for less productive firms, but a decrease in the pass-through for the more productive firms. A higher elasticity 
of substitution will link firms more strongly and thus firms with no foreign sales will be exposed to the exchange rate fluctuations.
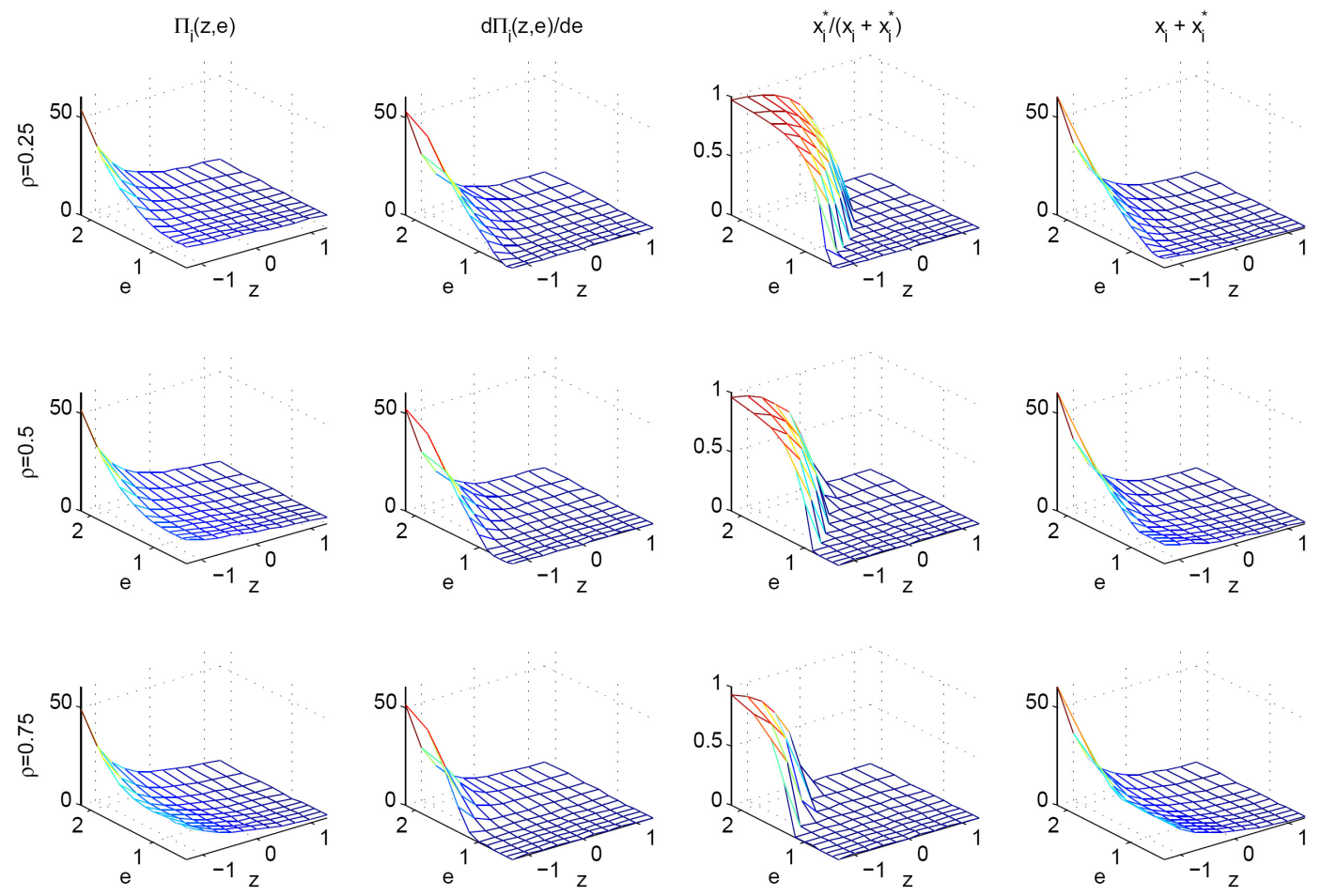

Figure 2: Profits, Sensitivity of Profits, and Sales Policies. The left figures plot profits $\pi_{i}$ and the sensitivity of profits to the exchange rate $d \pi_{i} / d e$ as a function of the exchange rate $e$ and cost shock $z_{i}$. The right figures plot the optimal sales policies: percentage of exports $x_{i}^{*} /\left(x_{i}+x_{i}^{*}\right)$ and total production $\left(x_{i}+x_{i}^{*}\right)$ as a function of the exchange rate $e$ and cost shock $z_{i}$. Each row corresponds to a different values of the elasticity of substitution, $\rho \in\{0.25,0.5,0.75\}$.

\subsection{Financing Policy}

The parameters of the idiosyncratic cost process -persistence $\rho_{z}$ and volatility $\sigma_{e}$ - have been chosen such that the trade-off between tax benefits and expected cost of default implies an average leverage in the simulations that matches the mean leverage in the data, defined as (Debt/Assets). The model cannot been calibrated to match the quantity of dollar debt observed in the data, it is an optimal hedging decision by firms. Therefore the share of dollar debt that comes out of the model can be thought as an over-identifying restriction for the model.

The economy is simulated for a panel of 500 firms over 500 periods. The first 100 periods in the simulated sample is dropped in order to mitigate the effect of the initial conditions. Summary statistics of the firms' optimal policies along with the data counterpart are given in Table 8.

As can be seen, most of the calibrated moments on the real side are reasonably close the data moments in the overall economy, that is for the sample of all firms (first two columns). The share of the 

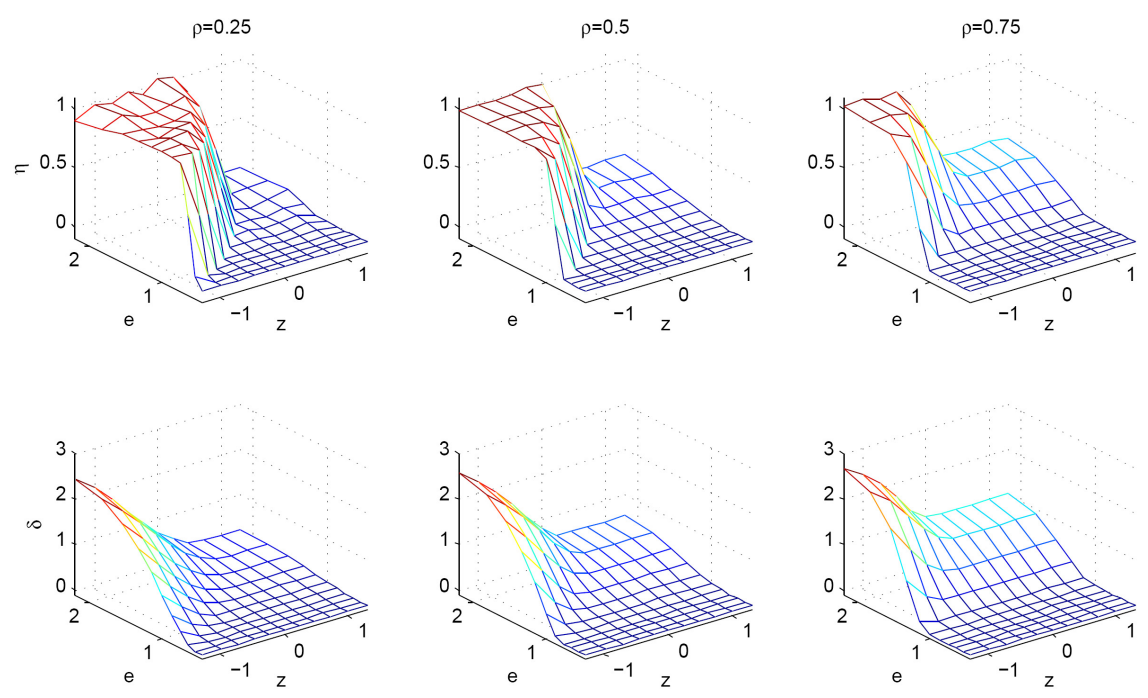

Figure 3: Pass-through and Exposure. The figure shows the pass-through $\eta$ (top row) and exposure $\delta$ (bottom row) as a function of the exchange rate $e$ and cost shock $z_{i}$. Each column corresponds to a different values of the elasticity of substitution, $\rho \in\{0.25,0.5,0.75\}$.

\begin{tabular}{|c|c|c|c|c|c|c|c|c|}
\hline Sample of firms & All & & Bin \#1 & (Local) & Bin \#2 & & Bin \#3 & (Exporter) \\
\hline Variable & Data & Model & Data & Model & Data & Model & Data & Model \\
\hline \multicolumn{9}{|l|}{ Real Side } \\
\hline Total Sales/Assets & 21.2 & 23.3 & 22.8 & 19.6 & 22.3 & 33.9 & 18.6 & 51.9 \\
\hline Domestic Sales/Assets & 18.3 & 20 & 22.8 & 19.6 & 21.1 & 24.2 & 10.9 & 19 \\
\hline Foreign Sales/Assets & 3 & 3.2 & 0 & 0 & 1.1 & 9.7 & 7.7 & 32.9 \\
\hline Profits/Assets & 1.6 & 1.7 & 1.8 & -1.4 & 1.8 & 9.4 & 1.1 & 27.3 \\
\hline \multicolumn{9}{|l|}{ Financing Side } \\
\hline Debt/Assets & 38.3 & 41.2 & 29.9 & 40.1 & 41.9 & 40.4 & 43.8 & 45.5 \\
\hline Foreign Debt/Assets & 16.3 & 16.7 & 4.6 & 14.6 & 15.9 & 24.1 & 28.9 & 29.7 \\
\hline Share of Foreign Debt & 36.7 & 36.8 & 14.9 & 32.5 & 34.1 & 53.8 & 62 & 61.8 \\
\hline
\end{tabular}

Table 8: Summary Statistics of Monte carlo Simulations. The economy is simulated for a panel of 500 firms over 500 periods (first 100 periods in the sample are dropped). All the numbers in this table are given in percentage points. 
foreign debt in the model is close to the data for the economy as a whole, at about $37 \%$.

\subsection{Hedging Behavior}

Firms find it optimal to borrow some of their debt in dollar denomination. But what is the purpose of issuing dollar debt. At this stage, the simulated data can be used to assess whether firms are using dollar denomination to hedge against the exchange rate risk. To evaluate this, I use the simulated data to reproduce the regressions ran in the empirical section (see Table 3). Given that firms are only different because they are hit by the exchange rate and idiosyncratic cost shocks, the right hand side of the regressions will only have the exchange rate shock,

$$
(\text { Sales } / \text { Assets })_{i t}=\alpha+\beta_{e} \log \left(e_{t}\right)+\varepsilon_{i t} .
$$

The results are reported in Table 9. The exchange rate beta of sales (more precisely the ratio of sales over assets) is positive and in line with the data. The exchange rate beta of earnings (more precisely the ratio of net earnings over assets) is forty times smaller than the sales beta. These estimates highlight the fact that firms use financial policies in order to reduce the fluctuations due to the exchange rate on cashflows. The model economy displays the same hedging behavior also observed in the data.

\begin{tabular}{lc|ccc}
\hline \hline & & Sales/Assets & Operating Income/Assets & Earnings/Assets \\
\hline \hline \multirow{2}{*}{ Data } & $\hat{\beta}_{e}$ & 0.067 & 0.006 & -0.009 \\
& t-stat & $(6.34)$ & $(1.65)$ & $(-1.13)$ \\
\hline \multirow{2}{*}{ Simulated data } & $\hat{\beta}_{e}$ & 0.100 & 0.080 & 0.002 \\
& t-stat & $(96.7)$ & $(85.8)$ & $(9.8)$ \\
\hline \hline
\end{tabular}

Table 9: Regression results using simulated data. The economy is simulated for a panel of 500 firms over 500 periods (first 100 periods in the sample are dropped).

\section{Conclusion}

In this paper I propose a model of production and financing decisions for firms in an open economy. I show that exchange rate fluctuations can potentially affect not only the profits of firms in the tradable sector, but also the profits of those in the non-tradable sector as well. In an economy where the product market is imperfectly competitive, the export decision of the exporting firms impacts the prices of all domestic goods. An implication of this channel is that local firms can potentially have a high exchange rate exposure. The motive to hedge these high currency exposures leads firms to use large amounts of dollar debt. Although it may seem that firms are taking on excessive dollar debt, they are in fact hedging the exchange rate sensitivity of their profits. This channel reconciles the puzzling fact that firms in emerging markets with no exports take on large shares of their debt in dollars. 
Using a panel of traded Mexican firms for the last ten years, I show that the sales of local firms are sensitive to the exchange rate, but that their earnings -defined as sales minus costs minus financing expenses- are not. This is evidence that local firms are effectively using financing policies -here the currency composition of their debt- to hedge the sensitivity of their sales to the exchange rate movements.

A quantitative model is used to study the effect of the goods market imperfection on the amount of foreign debt issued by local firms. The quantitative model includes a cross-section of firms, each hit with idiosyncratic cost shocks and an aggregate exchange rate shock. These firms interact in an imperfect product market and imperfect financial markets. Firms can issue defaultable debt and costly equity. Optimal leverage is a result of the tradeoff between tax shield and expected distress costs, and the optimal share of foreign debt arises from the motive to hedge the exposure profits. The model parameters are chosen to match some moments in the data. The calibrated model accounts for the amount of dollar debt observed in the Mexican firms data. This quantitative exercise supports the view that being able to borrow in dollar denomination provide firms with an economically important hedging tool against the risks associated with the exchange rate. 


\section{References}

[1] Michael Adler and Bernard Dumas. Exposure to currency risk: Definition and measurement. Financial Management, 13(2):41-50, 1984.

[2] Mark Aguiar. Investment, devaluation, and foreign currency exposure: The case of mexico. Journal of Development Economics, 78(1):95 - 113, 2005.

[3] George Allayannis and Jane Ihrig. Exposure and markups. Review of Financial Studies, 14(3):805$35,2001$.

[4] George Allayannis and Eli Ofek. Exchange rate exposure, hedging, and the use of foreign currency derivatives. Journal of International Money and Finance, 20(2):273 - 296, 2001.

[5] Hoyt Bleakley and Kevin Cowan. Corporate dollar debt and depreciations: Much ado about nothing? The Review of Economics and Statistics, 90(4):612-626, 082008.

[6] Gordon M. Bodnar, Bernard Dumas, and Richard C. Marston. Pass-through and exposure. The Journal of Finance, 57(1):199-231, 2002.

[7] Gordon M. Bodnar and William M. Gentry. Exchange rate exposure and industry characteristics: evidence from canada, japan, and the usa. Journal of International Money and Finance, 12(1):29 $-45,1993$.

[8] Gordon M. Bodnar, Gregory S. Hayt, and Richard C. Marston. 1998 wharton survey of financial risk management by us non-financial firms. Financial Management, 27(4):70-91, 1998.

[9] Gordon M. Bodnar and M. H. Franco Wong. Estimating exchange rate exposures: Issues in model structure. Financial Management, 32(1):35-67, 2003.

[10] Ricardo J. Caballero and Arvind Krishnamurthy. International and domestic collateral constraints in a model of emerging market crises. Journal of Monetary Economics, 48(3):513 - 548, 2001.

[11] Ricardo J. Caballero and Arvind Krishnamurthy. Excessive dollar debt: Financial development and underinsurance. The Journal of Finance, 58(2):867-893, 2003.

[12] Thomas F. Cooley and Vincenzo Quadrini. Financial markets and firm dynamics. The American Economic Review, 91(5):1286-1310, 2001.

[13] Kevin Cowan, Erwin Hansen, and Luis Oscar Herrera. Currency mismatches, balance sheet effects and hedging in chilean non-financial corporations. (346), December 2005.

[14] Peter M. DeMarzo and Darrell Duffie. Corporate incentives for hedging and hedge accounting. The Review of Financial Studies, 8(3):743-771, 1995.

[15] Kathryn M.E. Dominguez and Linda L. Tesar. Exchange rate exposure. Journal of International Economics, 68(1):188 - 218, 2006. 
[16] Kenneth A. Froot and Paul D. Klemperer. Exchange rate pass-through when market share matters. The American Economic Review, 79(4):637-654, 1989.

[17] Kenneth A. Froot, David S. Scharfstein, and Jeremy C. Stein. Risk management: Coordinating corporate investment and financing policies. The Journal of Finance, 48(5):1629-1658, 1993.

[18] Sebastian Galiani, Eduardo Levy Yeyati, and Ernesto Schargrodsky. Financial dollarization and debt deflation under a currency board. Emerging Markets Review, 4(4):340 - 367, 2003.

[19] Christopher Geczy, Bernadette A. Minton, and Catherine Schrand. Why firms use currency derivatives. The Journal of Finance, 52(4):1323-1354, 1997.

[20] Simon Gilchrist and Jae W. Sim. Investment during the korean financial crisis: A structural econometric approach. (WP2007-001), January 2007.

[21] Joao F. Gomes. Financing investment. The American Economic Review, 91(5):1263-1285, 2001.

[22] Joao F. Gomes and Lukas Schmid. Levered returns. The Journal of Finance, 2009.

[23] John R. Graham. How big are the tax benefits of debt? The Journal of Finance, 55(5):1901-1941, 2000.

[24] John R. Graham and Daniel A. Rogers. Do firms hedge in response to tax incentives? The Journal of Finance, 57(2):815-839, 2002.

[25] Christopher A. Hennessy and Toni M. Whited. Debt dynamics. The Journal of Finance, 60(3):1129$1165,2005$.

[26] Philippe Jorion. The exchange-rate exposure of u.s. multinationals. Journal of Business, 63(3):33145, July 1990.

[27] Richard C. Marston. The effects of industry structure on economic exposure. Journal of International Money and Finance, 20(2):149 - 164, 2001.

[28] Marc J. Melitz. The impact of trade on intra-industry reallocations and aggregate industry productivity. Econometrica, 71(6):1695-1725, 2003.

[29] Marc J. Melitz and Gianmarco I.P. Ottaviano. Market size, trade, and productivity. Review of Economic Studies, 75(1):295-316, 2008.

[30] Shehzad L. Mian. Evidence on corporate hedging policy. The Journal of Financial and Quantitative Analysis, 31(3):419-439, 1996.

[31] Deana R. Nance, Jr. Smith, Clifford W., and Charles W. Smithson. On the determinants of corporate hedging. The Journal of Finance, 48(1):267-284, 1993. 
[32] Sangeeta Pratap, Ignacio Lobato, and Alejandro Somuano. Debt composition and balance sheet effects of exchange rate volatility in mexico: a firm level analysis. Emerging Markets Review, 4(4):450 - 471, 2003.

[33] Martin Schneider and Aaron Tornell. Balance sheet effects, bailout guarantees and financial crises. The Review of Economic Studies, 71(3):883-913, 2004.

[34] Clifford W. Smith and Rene M. Stulz. The determinants of firms' hedging policies. The Journal of Financial and Quantitative Analysis, 20(4):391-405, 1985.

[35] Rene M. Stulz. Optimal hedging policies. The Journal of Financial and Quantitative Analysis, 19(2):127-140, 1984.

[36] Rene M. Stulz. Managerial discretion and optimal financing policies. Journal of Financial Economics, 26(1):3-27, 1990.

[37] Rohan Williamson. Exchange rate exposure and competition: evidence from the automotive industry. Journal of Financial Economics, 59(3):441 - 475, 2001. 